\section{$\mathrm{Y}-12$}

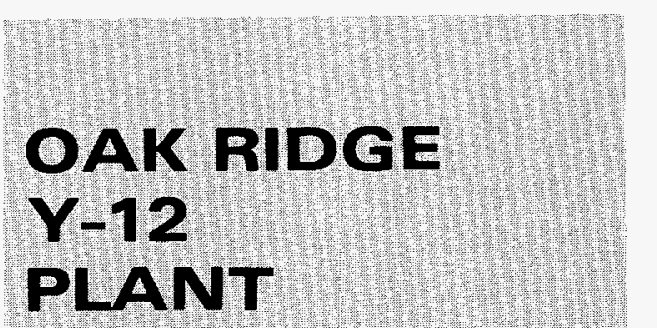

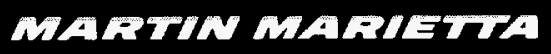

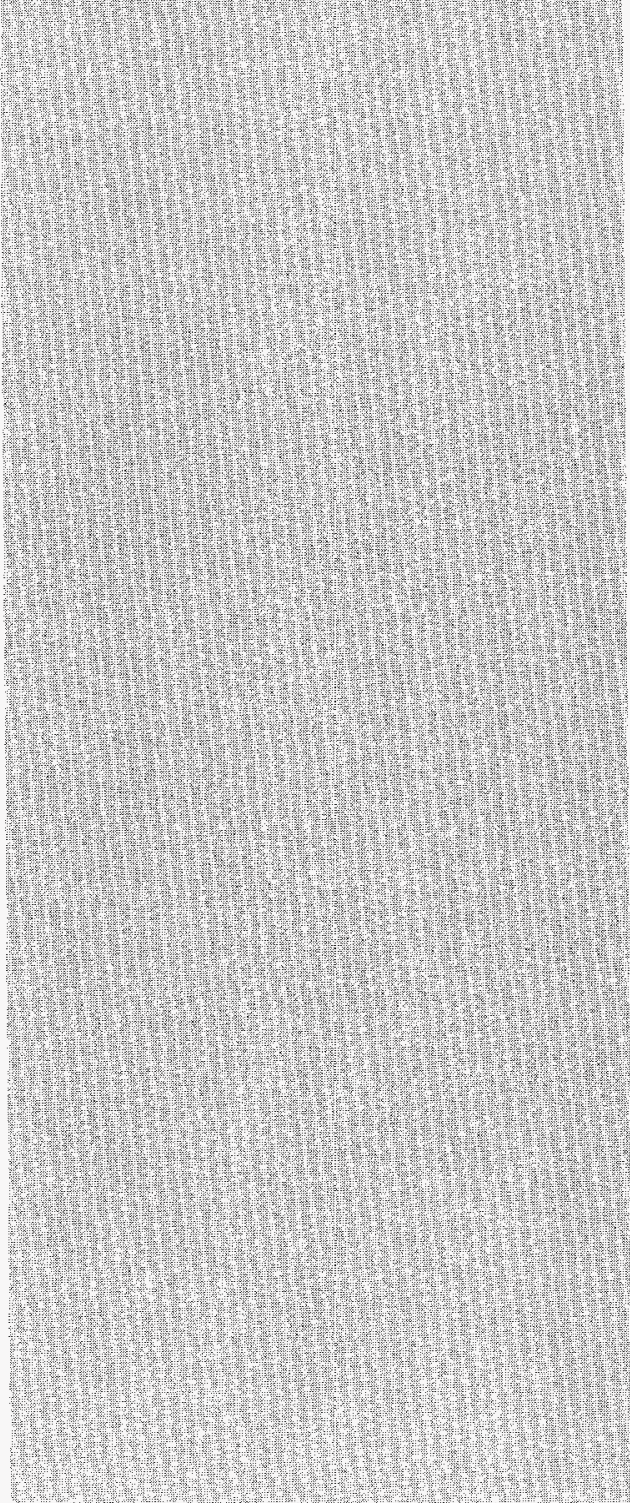

MANAGED BY

MARTIN MARIETTA ENERGY SYSTEMS, INC. FOR THE UNITEO STATES

DEPARTMENT OF ENERGY

\section{GUIDELINES FOR SELECTION \\ OF RADIOLOGICAL PROTECTIVE \\ HEAD COVERING GEIVED \\ JAN 041995 \\ OSTI}

G. R. Galloway, Jr.

Radiological Engineering Section

Radiological Control Department

August, 1995
DISTRIBUTION OF THIS DOCUMENT IS UNLIMITED 


\section{DISCLAIMER}

This report was prepared as an account of work sponsored by an agency of the United States Government. Neither the United States Government nor any agency thereof, nor any of their employees, makes any warranty, express or implied, or assumes any legal liability or responsibility for the accuracy, completeness, or usefulness of any information, apparatus, product, or process disclosed, or represents that its use would not infringe privately owned rights. Reference herein to any specific commercial product, process, or service by trade name, trademark, manufacturer, or otherwise, does not necessarily constitute or imply its endorsement, recommendation, or favoring by the United States Government or any agency thereof. The views and opinions of authors expressed herein do not necessarily state or reflect those of the United States Government or any agency thereof. 


\title{
GUIDELINES FOR SELECTION OF RADIOLOGICAL PROTECTIVE HEAD COVERING
}

\author{
G. R. Galloway, Jr. \\ Radiological Engineering Section \\ Radiological Control Department
}

August, 1995

\author{
Prepared by the \\ Oak Ridge Y-12 Plant \\ P.O. Box 2009. Oak Ridge, Tennessee 37831-8169 \\ managed by \\ LOCKHEED MARTIN ENERGY SYSTEMS, INC. \\ for the \\ U.S. DEPARTMENT OF ENERGY \\ under contract DE-AC05-84OR21400
}




\section{DISCLAMIER}

Portions of this document may be illegible in electronic image products. Images are produced from the best available original document. 


\section{Introduction}

The hood is recognized throughout the nuclear industry as the standard radiological protective head covering for use in radioactively contaminated work environments. As of June 15, 1995, hoods were required for all activities performed in contaminated areas at the Y-12 Plant. The use of hoods had historically been limited to those radiological activities with a high potential for personnel contamination. Due to the large size of many posted contaminated areas at the Y-12 Plant, and compounding safety factors, requirements for the use of hoods are being reevaluated. The purpose of the evaluation is to develop technically sound guidelines for the selection of hoods when prescribing radiological protective head covering.

\section{Guidance on Selection of Radiological Protective Clothing}

Title 10 of the Code of Federal Regulations, Part 835 (10 CFR 835), Article 404(g) states that protective clothing shall be required for entry to areas in which removable contamination exists at levels exceeding the surface radioactivity values specified in appendix $\mathrm{D}$ to Part 835 . The removable surface radioactivity value for uranium and associated decay products is $1,000 \mathrm{dpm} / 100 \mathrm{~cm}^{2}$ alpha or beta-gamma.

The DOE Radiological Control Manual (RCM), Article 325.1, states that personnel shall wear protective clothing during the following activities:

- Handling of contaminated materials with removable contamination in excess of Table 2-2 Levels $\left(1,000 \mathrm{dpm} / 100 \mathrm{~cm}^{2}\right.$ alpha or beta-gamma for uranium and associated decay products)

- Work in Contamination, High Contamination and Airborne Radioactivity Areas

- As directed by the Radiological Control Organization (RADCON) or as required by the Radiological Work Permit (RWP).

Article 325.4 adds that personal protective equipment and clothing shall be selected as prescribed by the controlling RWP and refers to general guidelines for protective clothing selection and use provided in Appendix 3C and Table 3-1 to the RCM.

Appendix 3C, Item 2, states that protective clothing as prescribed by the RWP should be selected based on the contamination level in the work area, the anticipated work activity, worker health considerations, and regard for nonradiological hazards that may be present, and refers to Table 3-1 for general guidelines on selection. A full set and double set of protective clothing is described as typically including:

$\begin{array}{ll}\text { Full Set of Protective Clothing } \\ \text { - } & \text { Coveralls } \\ \text { - } & \text { Gotton glove liners } \\ \text { - } & \text { Shoves covers } \\ \text { - } & \text { Rubber overshoes } \\ & \text { Hood }\end{array}$


Double Set of Protective Clothing

- Two paris of coveralls

- Cotton glove liners

- Two paris of gloves

- Two pairs of shoe covers

- Rubber overshoes

- Hood

RCM Table 3-1, Guidelines for Selecting Protective Clothing $(P C)$, is reproduced below:

\begin{tabular}{|c|c|c|c|}
\hline \multirow{2}{*}{ WORK ACTIVITY } & \multicolumn{3}{|c|}{ REMOVABLE CONTAMINATION LEVELS } \\
\hline & $\begin{array}{l}\text { LOW } \\
\text { (1 to } 10 \text { times Table } \\
2-2 \text { values) }\end{array}$ & $\begin{array}{l}\text { MODERATE } \\
\text { (10 to } 100 \text { times } \\
\text { Table } 2-2 \text { values) }\end{array}$ & $\begin{array}{c}\text { HIGH } \\
\text { (>100 times Table } \\
2-2 \text { values) }\end{array}$ \\
\hline Routine & Full set of PCs & Full set of PCs & $\begin{array}{l}\text { Full set of PCs, } \\
\text { double gloves, } \\
\text { double shoecovers }\end{array}$ \\
\hline Heavy work & $\begin{array}{l}\text { Full set of PCs, work } \\
\text { gloves }\end{array}$ & $\begin{array}{l}\text { Double set of PCs, } \\
\text { work gloves }\end{array}$ & $\begin{array}{l}\text { Double set of PCs, } \\
\text { work gloves }\end{array}$ \\
\hline $\begin{array}{l}\text { Work with } \\
\text { pressurized or large } \\
\text { volume liquids, } \\
\text { closed system breach }\end{array}$ & $\begin{array}{l}\text { Full set of } \\
\text { non-permeable PCs }\end{array}$ & $\begin{array}{l}\text { Double set of PCs } \\
\text { (outer set } \\
\text { non-permeable), } \\
\text { rubber boots }\end{array}$ & $\begin{array}{l}\text { Double set of PCs } \\
\text { and non-permeable } \\
\text { outer clothing, } \\
\text { rubber boots }\end{array}$ \\
\hline
\end{tabular}

Note:

For hands-off tours or inspections in areas with removable contamination at levels 1 to 10 times the values in Table 2-2, labcoats, shoecovers and gloves may be used instead of full PCs.

10 CFR 835 and the RCM do not require the use of hoods for specific radiological conditions or operations. The RCM, however, recommends the use of hoods for all routine work in contaminated areas with removable contamination exceeding Table 2-2 levels. Ultimately, the selection of radiological protective clothing is the responsibility of RADCON.

\section{Personnel Occurrence Data for the Y-12 Plant}

From January 1, 1994, to June 30, 1995, there were 142 Category III personnel contamination incidents at the Y-12 Plant. Of these 142 incidents, 11 involved contamination of the head or neck area. 9 of these 11 contaminations occurred in 1994, during which time there were approximately 960,000 contaminated area exits. Specific information on the 11 incidents is given below: 


\begin{tabular}{|c|c|c|c|c|}
\hline BLDG & AREA & $\begin{array}{l}\text { EMPLOYEE'S } \\
\text { ORGANIZATION }\end{array}$ & $\begin{array}{l}\text { LOCATION OF } \\
\text { CONTAMINATION }\end{array}$ & COMMENTS \\
\hline 9212 & $\begin{array}{l}\text { C-1 } \\
\text { Wing }\end{array}$ & $\begin{array}{l}\text { Facilities } \\
\text { Management } \\
\text { Organization (FMO) }\end{array}$ & forehead at hairline & $\begin{array}{l}\text { hood worn, bumped } \\
\text { head on pipe } \\
\text { exposing forehead }\end{array}$ \\
\hline 9212 & BCS 22 & FMO & hat & $\begin{array}{l}\text { welding in } \\
\text { contaminated area }\end{array}$ \\
\hline 9212 & BCS 22 & FMO & hair & $\begin{array}{l}\text { hood worn, bumped } \\
\text { head exposing hair }\end{array}$ \\
\hline 9204-2E & BCS 43 & FMO & hair & $\begin{array}{l}\text { hood worn, scraped } \\
\text { top of head }\end{array}$ \\
\hline 9206 & Room 5 & $\begin{array}{l}\text { Enriched Uranium } \\
\text { Operations (EUO) }\end{array}$ & neck & $\begin{array}{l}\text { hood worn, elastic } \\
\text { on hood broke } \\
\text { during doffing }\end{array}$ \\
\hline $9204-4$ & $\begin{array}{l}\text { Press } \\
\text { Area }\end{array}$ & $\begin{array}{l}\text { Mechanical } \\
\text { Operations }\end{array}$ & neck & $\begin{array}{l}\text { oil dripping from } \\
\text { press }\end{array}$ \\
\hline 9212 & BCS 22 & FMO & hat & $\begin{array}{l}\text { hood worn, welding } \\
\text { in contaminated } \\
\text { area, touched hat } \\
\text { with gloves }\end{array}$ \\
\hline 9212 & BCS 22 & EUO & hat & $\begin{array}{l}\text { hood worn, touched } \\
\text { hat with gloves }\end{array}$ \\
\hline 9212 & Post 57 & EUO & hat & \\
\hline 9212 & $\begin{array}{l}\text { E-Wing } \\
\text { Room } \\
1008 \\
\text { and } \\
1009 \\
\end{array}$ & FMO & neck & $\begin{array}{l}\text { hood worn, sawing } \\
\text { on contaminated } \\
\text { item, dust settled in } \\
\text { gap between } \\
\text { respirator and hood }\end{array}$ \\
\hline 9212 & $\begin{array}{l}\text { B-1 } \\
\text { Wing }\end{array}$ & FMO & neck & $\begin{array}{l}\text { chemical hood worn, } \\
\text { liquid dripped on } \\
\text { hood and clothing }\end{array}$ \\
\hline
\end{tabular}

The following observations can be drawn from this incident information:

- 8 of the 11 incidents occurred in Building 9212.

- 7 of the 11 incidents involved FMO personnel.

- 9 of the 11 incidents involved activities with a high risk of contamination for which head covering was worn. 
Although only a small percentage $(7.7 \%)$ of the personnel contamination incidents involved the head or neck area, the goal is zero. The majority of head contaminations occurred during activities that involved a higher risk of contamination, such as maintenance work. It is also evident that Building 9212 presents the greatest potential for head contamination. In all of the incidents involving higher risk activities, head coverings were worn. It cannot be determined whether these head coverings provided the same level of protection as those currently in use. Other factors contributing to these incidents included:

- Head covering compromised.

- Improper doffing of protective clothing/equipment.

- Protective clothing not taped.

- Use of protective clothing not intended for liquids.

\section{Radiological Controls and the Radiological Work Environment}

Radiological controls and the radiological work environment at the Y-12 Plant have changed considerably over the past two years. Major changes that should be considered in the selection of radiological protective clothing, including head coverings, are:

- $\quad$ Radiological Worker II (RW II) Training for all Rad Workers.

- Use of RWPs to control all radiological work.

- $\quad$ Radiological postings consistent with the RCM.

- Implementation of standard radiological protective clothing requirements.

- Emphasis on reduction in size and number of contaminated areas.

The purpose of RW II Training is to provide all personnel working in contaminated areas training on proper radiological and As Low As Reasonably Achievable (ALARA) practices. Prior to RW II there was no training that provided such instruction. As a result of RW II training, the Y-12 workforce is better educated for work in contaminated areas, and is more aware of practices to prevent the spread of radioactive contamination, e.g. proper doffing technique for radiological protective clothing.

The implementation of RWPs has resulted in more stringent control of work in contaminated areas. RWPs, which had historically been used to control only higher risk activities, are now required for all activities in contaminated areas. RWPs are used to delineate activity-specific protective clothing and contamination control requirements. The use of RWPs allows the flexibility to prescribe varying degrees of protective clothing as warranted by the specific activity and radiological conditions of the area.

The implementation of standard radiological protective clothing requirements in contaminated areas has greatly reduced the potential for personnel contaminations. Specific changes in protective 
clothing requirements which help reduce the potential for head contaminations, in addition to the use of hoods, include:

- Removal of outer gloves prior to doffing other protective clothing.

- Prohibiting the donning of protective equipment/clothing in contaminated areas.

- $\quad$ Requiring that protective clothing be taped.

- $\quad$ Prohibiting the reuse of protective/equipment clothing that comes in contact with unprotected areas of the body before it is laundered or surveyed by RADCON.

The radiological postings and size of contaminated areas at the $\mathrm{Y}-12$ Plant presents a challenge in the selection of radiological protective clothing. Although there is a continued emphasis on reducing the size of posted contaminated areas, numerous large contaminated areas still exist. The presence of large posted contaminated areas results in the entire area being considered contaminated, while the levels of removable contamination may vary greatly within the area. Many areas within posted contaminated areas may have removable contamination less than Table 2-2 levels, while specific areas exceed 10 times Table 2-2 levels. This condition causes difficulty in prescribing radiological protective clothing requirements for work in these areas.

\section{Criteria for Selection of the Hood as Radiological Protective Head Covering}

Selection of the hood as radiological protective head covering should be based on the following criteria (see Appendix for flow chart of criteria). These criteria were developed using the background information presented in the previous sections of this document. All criteria should be considered prior to prescribing the required protective head covering.

- Removable contamination levels in the work area.

- Work activity.

- Other activities in the work area.

- Potential for overhead sources of contamination.

- Worker health and safety.

- $\quad$ Nonradiological hazards present.

Hoods should be required for all entries into areas with removable contamination greater than 10 times Table 2-2 levels, regardless of the work activity. In large contaminated areas where the levels of removable contamination vary greatly, the need for hoods should be based on the levels of removable contamination expected to be encountered in the immediate work area, not the highest levels in the entire contaminated area.

If removable contamination in the area is less than 10 times Table $2-2$ levels, the need for hoods should be based on the specific work activity. The following activities present a high risk of head 
contamination and should always require the use of hoods:

- Work requiring a respirator.

- Work requiring a double set of protective clothing.

- Work which may result in removable contamination exceeding 10 times Table $2-2$ levels.

- Work which involves the breach of radioactive process containment.

- Work with uncontained, dispersible radioactive material, e.g. powders.

- Work with liquid radioactive material when a splash potential exists.

- Work in which personnel are reaching above their heads.

- Work requiring personnel to crawl over or under contaminated surfaces.

- Work in space-restricted areas where there is a potential for brushing against contaminated surfaces.

- Work involving crawling or laying on contaminated surfaces.

Most maintenance work in contaminated areas will involve one or more of the above mentioned activities and will require the use of hoods.

The following activities present a low risk of head contamination and generally do not require the use of hoods. The use of alternate head coverings may be considered.

- $\quad$ Routine work that does not involve any of the high risk activities listed above.

- Hands-off tours, inspections, and walk-throughs.

Other activities being performed in the work area should always be considered when determining if hoods are required. If these activities could present a risk of head contamination to personnel not specifically involved in the activities, hoods should be required of all personnel entering the area.

Regardless of the activity, the potential for overhead sources of contamination must be assessed prior to determining if a hood is required. Overhead sources of contamination include:

- Contaminated objects/obstructions at head level, e.g. pipes, ductwork, etc.

- Overhead pipes or process equipment containing liquid radioactive material that leak or drip, e.g. uranyl nitrate solution lines.

- Overhead ductwork or process equipment containing dry radioactive material that are open or deteriorated, e.g. process ventilation ductwork.

- Occupied areas overhead which are contaminated and do not have solid walking surfaces, c.g. 
grated mezzanines.

Hoods should be required in all areas where overhead sources of contamination are present.

Two nonradiological concerns that may preclude the use hoods are overall worker health and safety and other workplace hazards. Specific hazards presented by the use of hoods include obstruction of vision, an increase in heat stress, and use around rotating machinery. These hazards are assessed by other health and safety disciplines.

In the event it is determined hoods are not required for a specific radiological activity (based on the above criteria), an alternate type of head covering that provides less protection may be worn in lieu of the hood.

\section{Conclusion}

Hoods are not specifically mandated by 10 CFR 835 or the RCM, and are not necessary for all activities in contaminated areas at the Y-12 Plant. An alternate type of head covering that provides less protection is suitable as radiological protective head covering for many activities in Y-12 Plant contaminated areas. An evaluation of recent personnel contamination incidents, improvements in radiological controls, and the size of contaminated areas supports this position. The criteria set forth in this document should be used as guidance by RADCON personnel in the selection of radiological protective head covering for work in contaminated areas at the Y-12 Plant. 


\section{APPENDIX}

\section{CRITERIA FOR SELECTION OF RADIOLOGICAL PROTECTIVE HEAD COVERING}

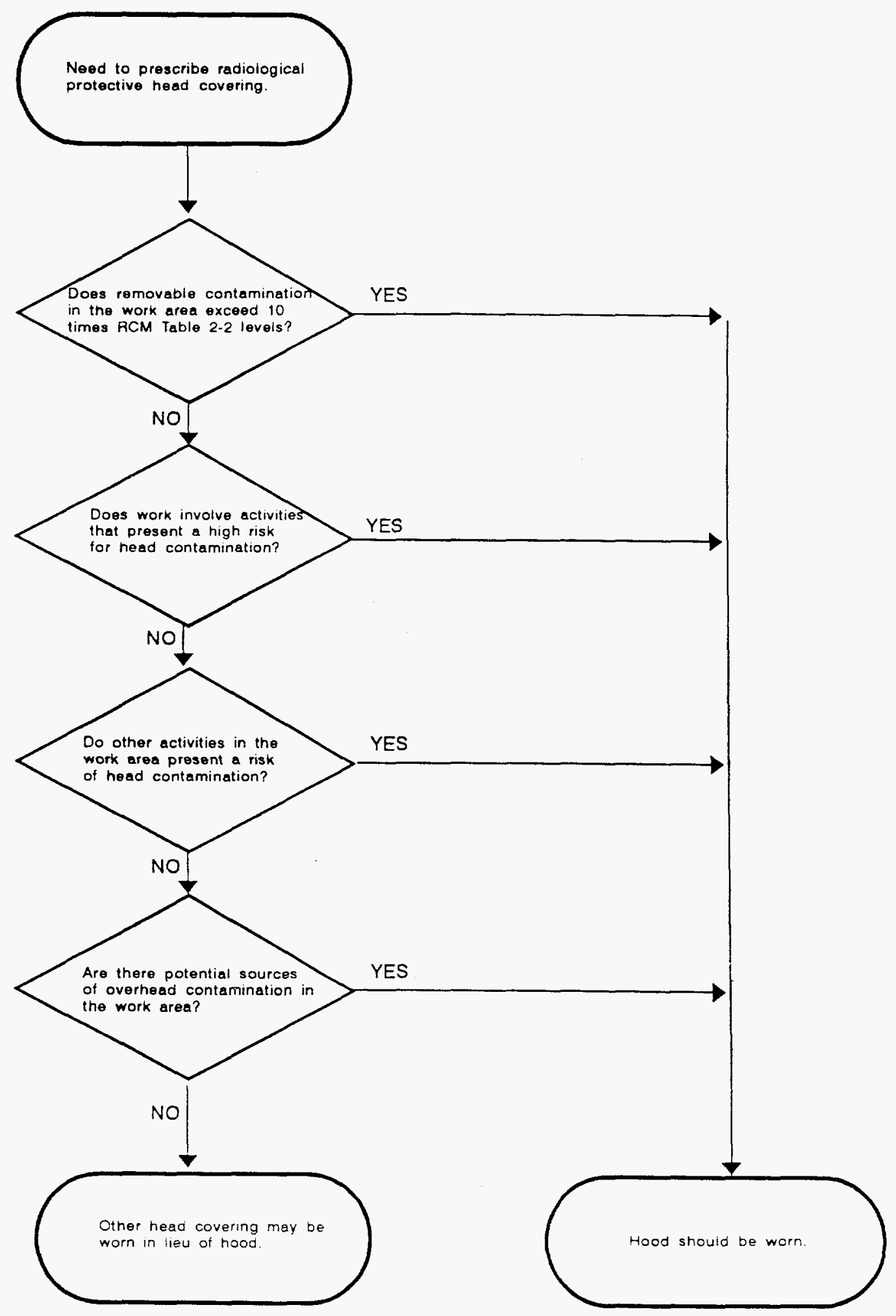




\section{DISTRIBUTION}

Aloi, T. J.

Ballard, S. B.

Barker, J. H.

Barnes, M. D.

Bogard, R. S.

Bowers, B. G.

Branum, K. W.

Brown, C. L.

Bryant, L. W.

Brynestad. A.

Cox, R. D.

Denton, T. J.

Eagle, G. T.

England, C. A.

Fortune, B. R.

Gass, J. D.

Hamby, R. A.

Kerwin, K. M.

Keyser, R. M.

Ludwig, F. J.

Ortiz, R. N.

RADCON - RC

Rowan, D. P.

Rowan, S. D.

Swenson, D. E.

Thomas, J. M. 